\title{
Rocks and ores of the PGE-bearing Vuruchuaivench massif (Kola Peninsula, Russia)
}

\author{
Aleksey Pakhalko \\ A.P. Karpinsky Russian Geological Research Institute (VSEGEI); Saint-Petersburg, Russia; e-mail: Aleksey_Pahalko@vsegei.ru \\ (C) 2015 Authors. This is an open access publication, which can be used, distributed and reproduced in any medium according \\ to the Creative Commons CC-BY 4.0 License requiring that the original work has been properly cited.
}

The early Palaeoproterozoic mafic-ultramafic layered Monchegorsk pluton is located in the north-eastern Fennoscandian (Baltic) Shield, on the Kola Peninsula. The Monchegorsk pluton is the second largest layered pluton in Europe $\left(\mathrm{ca} .60 \mathrm{~km}^{2}\right)$, and consists of two branches: one N-E trending (the Nittis, Kumuzh'ya, and Travyanaya (NKT) massifs), and sublatitude trending (the Sopcha, Nud, and Poaz massifs). The Vuruchuaivench massif occurs at the marginal part of the Nyud-Poaz intrusions (Smolkin et al. 2003). The Vuruchuaivench massif entirely consists of hydrothermally altered gabbronorite that is exposed in separated outcrops (ranging from meters to tens meters) northeastwards for a distance of 7-8 km, and disappears in Lake Imandra (Ivanchenko 2008). The width of the exposure is $1.5-2.0 \mathrm{~km}$. The intrusive is known for its PGE mineralization (prognostic resources $100 \mathrm{t}$ of PGE). Reef ore body is similar with Platinova (Skaergaard) and Sonju Lake (Duluth Complex) PGE reefs. Rock ores are presented by metasomatised taxitic leucogabbronorites and anortosites (Knauf et al. 2008; Smolkin et al. 2003). The reef ore body hosts low-sulphide Ni-Cu and PGE mineralization. Average content of PGE in rocks is 2.0-2.5 ppm, samples containing $19 \mathrm{ppm}$ are also found (Knauf et al. 2008). The ratio of Pd/Pt varies from 2-8:1.

The samples (13 samples) were selected from the detailed study area $\left(0.03 \mathrm{~km}^{2}\right)$. Petrographic features were studied using optical microscope and X-ray analysis. The trace elements and precious metals analysis was performed with ICP-MS.
Isotopic research was provided with SHRIMP-II. All analyses were carried out in A.P. Karpinsky Russian Geological Research Institute (VSEGEI) in Saint-Petersburg.

The presence of a propylite rock was established for the first time in the territory of massif. Two propylite groups that differ mineralogically were identified. PGE mineralization is associated with the quartz-chlorite-albite group, whereas mineralization is unrelated with another, the albite group. There is a difference in total REE content in gabbronorites and propylites. Propylites of first group differ from second group and gabbronorites by a noticeable spread of values in REE content. The similarities of REE patterns in all rocks may indicate a genetic relationship. Arsenides and sulphoarsenides are predominant among the platinum group minerals in the Vuruchuaivench massif. The age of the propylites (based on $\mathrm{Rb}$ $\mathrm{Sr}$ isotopic system) is $2,470 \pm 130 \mathrm{Ma}$. The Initial ${ }^{87} \mathrm{Sr}{ }^{86} \mathrm{Sr}$ ratio $\left(\mathrm{I}_{\mathrm{Sr}}=0.703537\right)$ and $\delta^{34} \mathrm{~S}=1.4 \%$ (Grokhovskaya et al. 2009) indicate a slight part of a crustal component in formation of rocks and ores of the Vuruchuaivench massif.

\section{REFERENCES}

Grokhovskaya T.L., Tevelev A.V. \& Nosik L.P., 2009. Processy formirovaniya platinometallnoi mineralizacii v massive Monchetudra, Kolskiy poluostrov. Proceedings of All-Russian Conference "Metallogeniya Dokembriya", Petrozavodsk, Russia, 84-89 [in Russian].

Ivanchenko V.N., Davydov P.S., Dedeev V.A. \& Knauf V.V., 2008. Major features of the Vuruchuaivench deposit 
geological structure. [in:] International Collaboration Project of KOLARCTIC INTERREG III A North - TACIS N KA-0197 "Strategic mineral resources as a basis of sustainable development of the North" (Russia - Finland Sweden), KSC RAS, Apatity, Russia, 83-89.

Knauf V.V., Davydov P.S. \& Ivanchenko V.N., 2008. The platinum group elements and gold mineralization on Vuruchuaivench prospecting area. [in:] International Collaboration Project of KOLARCTIC INTERREG III A North - TACIS N KA-0197 "Strategic mineral resources as a basis of sustainable development of the North" (Russia - Finland - Sweden), KSC RAS, Apatity, Russia, 89-99.

Sharkov E.V. \& Chistyakov A.V., 2012. The Early Paleoproterozoic Monchegorsk Layered Mafite-Ultramafite Massif in the Kola Peninsula. Geology, Petrology, and Ore Potential Petrology, 20, 7, 607-640.

Smolkin V.F., Fedotov Zh.A., Neradovsky Yu.N. et.al, 2003. Layered intrusions of the Monchegorsk ore region: petrology, mineralization, isotopy, deep structure. KSC RAS, Apatity, Russia [in Russian]. 